\title{
岡山大学勤務医師による非常勤勤務を通した地域医療支援の現状調查
}

\author{
勅使川原早苗 ${ }^{\mathrm{*}}$ ，岩 瀬 敏 秀b，金 森 達 也 ${ }^{\mathrm{a}}$, 川 畑 智子 ${ }^{\mathrm{a}}$, \\ 佐藤勝 ${ }^{a}$, 片岡仁美 ${ }^{a}$
}

a岡山大学大学院医歯薬学総合研究科 地域医療人材育成, b岡山県地域医療支援センター 岡山大学支部

\section{Okayama University Survey of the current situation of community-based medical facilities supported by part-time work by physicians}

\author{
Sanae Teshigawara ${ }^{a *}$, Toshihide Iwase ${ }^{\mathrm{b}}$, Tatsuya Kanamoria, Tomoko Kawabata ${ }^{\mathrm{a}}$, \\ Masaru Sato ${ }^{a}$, Hitomi Usui Kataoka ${ }^{a}$

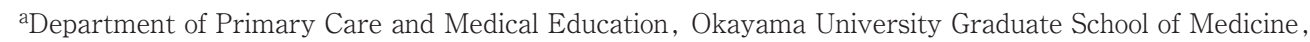 \\ Dentistry and Pharmaceutical Sciences, Okayama 700-8558, Japan, bSupport Center for Medical Cooperation, \\ Human Resource Placement and Career Promotion of Okayama Prefecture, Okayama 700-8558, Japan
}

\begin{abstract}
We investigated the situation of how physicians at Okayama University support local medical institutions by serving as a part-time worker, and analyzed the difference between the five medical districts of Okayama prefecture and other prefectures. Many physicians (actual number of physicians, full-time equivalent number of physicians) served in the southeastern region of the Okayama prefecture $(339,82.2)$. On the other hand, fewer physicians $(42,11.4)$ served in Takahashi - Niimi in the northwestern region of Okayama. Many physicians also served in Hiroshima prefecture $(193,48.8)$, Hyogo prefecture $(109,26.7)$, and the four prefectures of Shikoku Island $(81,23.6)$.

It has been clarified that many physicians at Okayama University are working on a part-time basis to support local and community medical institutions in the wide area of Okayama prefecture, Hiroshima prefecture, Hyogo prefecture and the four prefectures of Shikoku Island.
\end{abstract}

キーワード：岡山大学勤務医師 (physicians at Okayama University), 非常勤勤務 (part-time worker), 地域医療機関支援 (community-based medical facilities)

\section{諸言}

岡山県は, 人口約194万人 (全国第21位), 面積は約 7 千 平方キロメートル（全国17位）で，県内15市（4区）10町 2 村からなる．南は瀬戸内海をはさんで四国に，北は山陰 地方に接し，東は兵庫県，西は広島県に接しており，昔か ら中四国地方の交通の要衝として重要な位置にあった。

二次医療圈は県南東部, 県南西部, 津山・英田 (県北東 部), 真庭 (県北中央部), 高梁・新見 (県北西部) の 5 つ であるが，人口は平野部である県南東部および県南西部医 療圈に集中している．基準病床数と既存病床数を比較する と, 津山・英田医療圈のみ基準病床数に 32 床足りていない ものの，他の 4 圈域については過剩となっている状況であ る（岡山県ウェブサイト http://www.pref.okayama.jp/ 平成 26 年 7 月閲覧).また, 岡山県の人口 10 万人当たり 医師数は, 290.2 人（岡山県ウェブサイト http://www.

平成 26 年 12 月 9 日受理

* 7 700-8558 岡山市北区鹿田町 2-5-1

電話：086-235-6963 FAX：086-235-6834

E-mail : teshig-s@cc.okayama-u.ac.jp pref.okayama.jp/平成26年 7 月閲覧）であり，県全体で は全国平均（226.5人）を上回っている（厚生労働省ウ エブサイト http://www.mhlw.go.jp/toukei/saikin/hw/ ishi/12/index.html 平成26年 7 月閲覧）が，県北の津山・ 英田，真庭，高梁・新見の 3 医療圈では全国平均を下回っ ている（岡山地域医療支援センターウェブサイト http:// chiikiiryouokayama.wix.com/centerokayama\#!untitled/ cxkt 平成 26 年 7 月閲覧). 加えて, 各圈域で地域や診療科に よる偏在も見られている (厚生労働省ウェブサイト http:// www . mhlw.go.jp/toukei/saikin/hw/ishi/12/index.html 平成 26 年 7 月閲覧).そして, 高梁・新見, 真庭の 2 医療圈 では，他の医療圈に比べ常勤医師数に対して非常勤医師数 の割合が多いという状況が認められている（岡山地域医療 支援センターウェブサイト http://chiikiiryouokayama.wix. $\mathrm{com} /$ centerokayama\#! untitled/cxkt 平成26年 7 月閲覧).

岡山県は，へき地医療を支援するために平成 14 年 4 月 1 日に岡山県へき地医療支援機構を設置している。広域的な へき地医療支援事業の企画・調整等を行い，各種事業を円 滑かつ効率的に実施することを目的に，岡山済生会総合病 院が運営を受託している．知事が指定したへき地医療拠点 
病院は 9 施設あり, 巡回診療, 医師・歯科医師のへき地診療 所への派遣, 遠隔医療などの支援事業, へき地医療従事者の 研修, 代診医派遣などの事業を行っている(岡山県へき地医 療支援機構ウェブサイト http://www. okayamasaiseikai. or.jp/hekichi/index_html 平成26年 7 月閲覧).

また, 医師の偏在を是正するため, 平成 24 年 2 月 7 日, 岡 山県庁医療推進課内に「岡山県地域医療支援センター」が 開設された。同センターの岡山大学支部は岡山大学病院敷 地内に設置され, 県内の医師不足の状況を把握 - 分析し, 岡山大学掞よび広島大学の医学部地域枠学生と自治医科大 学生の地域医療実習支援㧍よび卒後のキャリア支援を行っ ている.

岡山大学医学部扔よび岡山大学病院の歴史は古く, 明治 3 年にさかのぼる. 2013年 6 月の時点での岡山大学の関連 病院は, 北は北海道から, 南は沖縄県に及び約 250 病院であ り, 岡山県内（約 120 病院）だけでなく中国地方（約 50 病 院）・四国（約55病院）・兵庫県（約 20 病院）を中心とした 様々な地域の医療を支えている。 大学病院は, 医育機関や 研究機関としての役割のみならず，地域の医療を支える役 割を期待され，また，その役割を担っていることが多い1,2). しかし，その実態を調べたデー夕は少ない。平成 22 年に岡 山大学地域医療人材育成講座が行った調査では, 県北地域 全体への医師派遣数は 152 人（常勤換算医師数：47.25人） であった。そこで今回は, 県内の二次医療圈及び近隣県に 対する岡山大学の医師による非常勤勤務での地域医療機関 への支援状況を把握するために調査を行った。

\section{対象と方法}

2013年 4 月に岡山大学医学部医学科および岡山大学病院 の71講座に対して,メールで調査票を配布した。調査票で は, 派遣先医療機関, 派遣実人数, 派遣先医療機関への週あ たり派遣日数の総和について聴取した，週あたり派遣日数 の総和については，日勤（8時間）を 1 日，待機当直（16 時間）を 1 日，救急などの夜勤（16時間）を 2 日として計 算を依頼した。講座は大きく基礎系と臨床系に分類した。
派遣先医療機関については，その所在地によって，県南東 部, 県南西部, 津山・英田, 真庭, 高梁・新見, 広島県, 兵庫県, 四国 4 県, その他,の 9 つの地域に分類した。さ らに，岡山市と倉敷市は多くの人口を抱えると共に医療施 設が多く分布していること，ならびに，高梁・新見は同じ 二次医療圈であるものの生活圈としては別であることを考 慮し, 県南東部を岡山市と岡山市以外の県南東部に, 県南 西部を倉敷市と倉敷市以外の県南西部に，高梁・新見を高 梁と新見に分けた。

また，医療法第 25 条第 1 項の規定に基づく立入検査要綱 に従って，週あたり 32 時間勤務を常勤 1 名となるよう派遣 先医療機関への週あたり派遣日数の総和から常勤換算非常 勤医師数を計算し，基礎系／臨床系㧍よび前述の地域ごと に層別した。そそして，住民基本台帳に基づく2012年 3 月31 日時点の人口および2011年度法定報告の医療機能情報に基 づき，岡山県の各地域の人口 10 万対の常勤換算非常勤医師 数と岡山大学の医師が占める割合を計算し, 地域で層別し て記述した。また，特に勤務環境が過酷で，全国的に医師 不足が問題となっている産婦人科，小児科については，岡 山大学から派遣される非常勤医師の地域の常勤換算非常勤 医師数に占める割合を補足的に解析した。

\section{結果}

調査票に対する回答を 51 講座より得た (回収率 $72 \%$ ). 未 回答の 20 部署の約半数は医師が所属していなかった. 岡山 大学から派遣される県内の各二次医療圈及び県外の医療機 関数は表 1 の通りであり, 病院が最も多く, 次いで診療所 への派遣が認められ，少数ながら健診機関，福祉施設，検 査機関, 血液センター, 大学保健管理センターへ派遣が行 われていた。派遣される県外の医療機関数は 100 施設以上で あった。

岡山大学から派遣される非常勤医師のうち診療に従事す る医師の実人数は基礎系 68 人, 臨床系 1,114 人の計 1,182 人 であった（表 2 )。常勤換算非常勤医師数は，基礎系18.6 人, 臨床系 287.4 人の計 306.0 人であった.

表 1 派遣される医療機関数

\begin{tabular}{c|c|c|c|c|c|c}
\hline 派遣される医療機関 & 県南東部 & 県南西部 & 津山・英田 & 真庭 & 高梁・新見 & 県外 \\
\hline 病院 & 63 & 39 & 11 & 7 & 6 & 101 \\
\hline 診療所 & 23 & 9 & 4 & 0 & 1 & 9 \\
\hline 健診機関 & 3 & 0 & 0 & 0 & 0 & 0 \\
\hline 福祉施設 & 2 & 1 & 0 & 0 & 0 & 1 \\
\hline その他*1 & 2 & 1 & 0 & 0 & 0 & 1 \\
\hline
\end{tabular}

(*1検査機関, 血液センター, 大学保健管理センター) 
岡山県の二次医療圈と県外の 4 地域の 9 つの地域で層別 した記述結果を表 3 に示す。岡山大学から派遣される診療 に従事する非常勤医師（実人数, 常勤換算医師数）は岡山 県内では県南東部 $(339$ 人, 82.2 人) と最も多く, 高梁・新 見（42人, 11.4 人）が最も少なかった. 岡山県以外では広 島県 (193人, 48.8 人), 兵庫県 ( 109 人, 26.7 人), 四国 4 県（81人， 23.6 人）の順に多く派遣されていた.

人口 10 万対で見ると，真庭が 31.7 人と最も多く，高梁・ 新見が 17.1 人と次点で, 県南西部が 7.3 人と最も少なかっ
た. 地域の常勤換算非常勤医師数に占める割合は，真庭が $52.8 \%$ と最も高く, 県南東部が $12.9 \%$ と最も低かった。

岡山県を 8 つ地域に層別した記述結果を表 4 に示す. 岡山大学加派遣される非常勤医師（実人数, 常勤換算医 師数）は岡山市 ( 246 人, 59.3 人) が最も多く，高梁 $(21$ 人， 4.4 人）が最も少なかった。人口 10 万対で見ると，真庭 が 31.7 人と最も多く, 新見が 21.2 人と次点で, 倉敷市が 5.6 人と最も少なかった。地域の常勤換算非常勤医師数に占め る割合は，真庭が $52.8 \%$ と最も高く，倉敷市以外の県南西

表 2 診療に従事する基礎系, 臨床系の医師数

\begin{tabular}{l|c|c|c}
\hline & 基礎系 & 臨床系 & 合計 \\
\hline 派遣される非常勤医師の実人数 (人) & 68 & 1,114 & 1,182 \\
\hline 派遣される常勤換算非常勤医師数 (人) & 18.6 & 287.4 & 306.0 \\
\hline
\end{tabular}

表 3 岡山県の二次医療圈と県外の 9 つの地域で層別した診療に従事する医師数分布（全科）

\begin{tabular}{|c|c|c|c|c|c|c|c|c|c|}
\hline & \multicolumn{5}{|c|}{ 岡山県 } & \multicolumn{4}{|c|}{ 岡山県以外 } \\
\hline $\begin{array}{l}\text { 岡山大学から派遣される非 } \\
\text { 常勤医師の実人数（人） }\end{array}$ & 339 & 202 & 79 & 54 & 42 & 193 & 109 & 81 & 20 \\
\hline $\begin{array}{l}\text { 岡山大学から派遣される常 } \\
\text { 勤換算非常勤医師数（人） }\end{array}$ & 82.2 & 52.6 & 21.7 & 16.1 & 11.4 & 48.8 & 26.7 & 23.6 & 5.8 \\
\hline $\begin{array}{l}\text { 地域の人口 } 10 \text { 万対の常勤換 } \\
\text { 算非常勤医師数 (人) }\end{array}$ & 70.4 & 29.8 & 40.0 & 60.0 & 65.5 & - & - & - & - \\
\hline
\end{tabular}

表 4 岡山県を 8 つ地域で層別した診療に従事する医師数（全科）

\begin{tabular}{|c|c|c|c|c|c|c|c|c|}
\hline & \multicolumn{8}{|c|}{ 岡山県 } \\
\hline $\begin{array}{l}\text { 岡山大学から派遣される常勤換算非常勤医師数 } \\
\text { (人) }\end{array}$ & 59.3 & 22.7 & 26.8 & 25.8 & 21.7 & 16.1 & 4.4 & 7.1 \\
\hline 地域の人口 10 万対の常勤換算非常勤医師数 (人) & 79.0 & 42.7 & 31.5 & 26.3 & 40.0 & 60.0 & 56.6 & 74.5 \\
\hline 地域の常勤換算非常勤医師数に占める割合 (\%) & 10.9 & 24.8 & 17.8 & 41.1 & 28.2 & 52.8 & 23.0 & 28.5 \\
\hline
\end{tabular}


部が $41.1 \%$ と次点で，岡山市が10.9\%と最も低かった.

また, 今回のデー夕から産婦人科と小児科について解析 したところ, 岡山大学産婦人科から派遣される非常勤医師 の地域の常勤換算非常勤医師数に締める割合は, 倉敷市以 外の県南西部が $39.2 \%$ と最も高く, 真庭が $35.6 \%$ と次点で あり, 岡山大学小児科から派遣される非常勤医師の地域の 常勤換算非常勤医師数に締める割合は, 真庭が $112.0 \%$ と 100\%を超えており,倉敷以外の県南西部が $49.1 \%$ と次点で あった。

\section{考察}

今回の調査で, 岡山大学は広島県・兵庫県・四国地方の 広範囲にわたる医療機関に対して非常勤勤務での医療支援 を行っていることがわかった。基礎系講座は常勤換算医師 数で臨床系部署の約 $6 \%$ 程度の支援を行っており, 基礎医 学研究者は年々減少傾向にある状況（文部科学省ウェブサ イト http://www.mext.go.jp/平成26年 7 月閲覧）の中, 岡山大学の基礎系講座の医師は臨床現場の支援も行ってい ることが明らかになった. また, 広島県, 兵庫県, 四国地方 などの岡山県外に派遣される常勤換算医師数は岡山県北部 の医療圈よりも多く, 岡山大学は県内のみならず, 県外の 医療も強力に支援していることが明らかとなった。一方， 人口 10 万対で見ると岡山県北部, 特に真庭, 高梁・新見に 支援が行われていた。さらに，二次医療圈をより細かく分 けることによって, 各地域の状況をより正確に記述するこ とができたと考えられる。例えば，倉敷市と倉敷市以外の 県南西部を比べると人口 10 万対の派遣される常勤換算非常 勤医師数に大きく差が認められたり，高梁と新見を比べる と新見のほうがより人口 10 万対の常勤換算非常勤医師数が 高かったりといったように詳細に地域の状況を明らかにで きた。岡山県南東部，岡山県南西部に限らず，医療資源の 豊富な都市を含む二次医療圈では，平均值としての医師数 が多くなるため, 同じ二次医療圈内に著しい医師不足地域 があっても統計上見過ごされやすい，という問題がある。 地域の課題を抽出する際には, 二次医療圈内の医師数の偏 在という問題にも留意する必要があるだろう。

医師の地域偏在と診療科偏在について, 特に過酷な労働 環境が問題視されている産婦人科医や小児科医の不足が全 国的な課題となっている. 厚生労働省が発表した「平成 24 年 医師・歯科医師・薬剤師調查の概況」(厚生労働省ウェブサ イト http://www.mhlw.go.jp/toukei/saikin/hw/ishi/12/ index.html 平成 26 年 7 月閲覧）によると, 産婦人科医は平 成14年から平成18年にかけて約千人減少し, その後は漸増 傾向であるものの, 平成24年の時点で平成14年の水準まで 回復していない状況である. 岡山大学産婦人科は, 中四国と
兵庫県を中心に約40の関連病院を持ち，それらの医療機関 と協力して地域医療を担い, 若手医師の育成を行っている. 平成15年の厚生労働大臣医療事故対策緊急アピールにおけ る医療安全対策として, 地域の中核となっている周産期医 療施設のオープン病院化が提言されたことを受け，全国に 先駆け平成18年 4 月より, 周産期医療施設オープン病院化 モデル施設として,「岡山大学周産期オープンシステム」を スタートし, 平成 26 年現在, 岡山市内 17 病院が参加してい る.さらに, 産科医師の減少に伴い, 地域で出産ができる医 療機関数が減少する中で, 津山地区および高梁地区の周産 期を支えるオープンシステムも構築した。また，周産期救 急の教育コースである Advanced Life Support in Obstetrics （ALSO）のセミナー導入，自治医科大学卒業生の産婦人 科施設での研修受け入れにも努めている。このように岡山 大学病院産婦人科は, 地域周産期母子医療センターとして 総合周産期母子医療センター, その他の地域周産期医療関 連施設と連携し，安全で安心な周産期医療体制の確保に取 り組んでいる（岡山県ウェブサイト岡山県周産期医療協議 会 http://www.pref.okayama.jp/page/detail-61755.html 平成26年 7 月閲覧).

岡山大学小児科においても卒後臨床研修制度の導入によ り, 大学病院医局体制が崩れ, 入局者の激減による地域への 大学病院からの医師派遣が極めて困難な事態となった。岡 山県の医療圈毎の小児科標榜病院数は, 県南東部と南西部 ではそれぞれ26病院, 27 病院であるが, 津山・英田では 7 病 院, 真庭には 2 病院, 高梁・新見地区では 1 病院であり, 岡山県の小児科学会会員（総 338 人）一人あたりの小児人口 は849人という現況である (https://view.officeapps. live. $\mathrm{com} / \mathrm{op} /$ view . aspx?src $=\mathrm{http} \% 3 \mathrm{~A} \% 2 \mathrm{~F} \% 2 \mathrm{Fjpsmodel}$. umin.jp\%2Fdata\%2FDOC\%2F20050910CombinationtCo mmittee.doc 平成26年 7 月閲覧).

そこで，日本小児科学会を中心に小児医療体制の再構築 が目指された (http://jpsmodel.umin.jp/formulation.html 平成 26 年 7 月閲覧). 岡山県に扔いては, 病院小坚科を機能 ごとに分けて役割分担化とネットワーク化を進め，さらに 地域医療を担う診療所・クリニックと連携して，小児医療 体制を構築することを目指している，小児科医が非常に少 ない真庭地区などに捛いては, 地元医師会と協力し, 診療 科の枠を超えた共働体制を構築し，小児の初期救急に対応 できない医療圈の解消を目指している. また, 今回の調査 で,小児科医師の割合が真庭において100\%を超えた点につ いては，2011年度に報告された医療機能情報と2013年 4 月 に行った本調査とで実施時期が異なるためと考えられた。

今回の調查でも岡山大学産婦人科・小児科から派遣され る非常勤医師による地域支援が行われていることが確かめ 
られたが，こうした専門科の医師の偏在も含め，今後の医 療提供体制については県の策定する地域医療ビジョンに基 づき, 県, 市町村, 地域医療機関, 地域医療教育を担う大 学が協議し, より望ましい医師派遣を検討していく必要が あると思われる ${ }^{3)}$. 地域への適切な医師派遣のためには, 住 民の人口構成, 疾病分類, 医療需要を把握することが必要 である ${ }^{4,6)}$. 地域医療支援センターの役割は, 医師偏在の是 正であるが，そのためには，医療機関，住民，行政との調 整や支援が求められる ${ }^{5)}$. 地域医療ミーティング等で，地 域医療への住民の意見・要望を直接話し合う機会を設け, また，住民の年齢別疾病分類 ・受診状況などの医療動向や 将来推計人口から予測される医療需要を分析することが, 各診療科の必要な派遣医師数を検討する際の一助となるで あろう。

大学病院の果たす役割は, 臨床, 研究, 教育の 3 つだけ でなく, 地域の医療機関への常勤・非常勤の医師派遣も挙 げられる。 今後, 地域枠学生が卒業し, 医師不足地域に若 手医師が赴任する状況においては，地域の医療現場の医師 だけでなく, 大学から派遣される医師の教育力の向上もよ り重要になると思われる ${ }^{1,2)}$.

\section{結 論}

岡山大学は岡山県 ・ 広島県 $\cdot$ 兵庫県 ・四国地方の広範囲 にわたる医療機関に対して非常勤勤務での支援を行ってい ることが明らかとなった。

\section{謝辞}

地域での支援状況につきましてご教示頂きました岡山大学医歯薬 学総合研究科産科・婦人科学教授平松祐司先生, 岡山大学医歯薬学総 合研究科小児医科学教授塚原宏一先生および岡山大学大学院保健学 研究科教授小田慈先生に深謝いたします。また調査票の記入にご協力 頂きました先生方, 事務員の方々に厚く御礼申し上げます.

\section{文献}

1 ）熊田恵介, 吉田隆浩, 豊田 泉, 小倉真治, 福田充宏: 大学病 院を中心とした地域医療支援のあり方一岐皁大学医学部付属病 院・地域医療医学センターでの取り組みを中心に一、へき地・ 離島救急医研会誌（2010）11，56-59.

2 ）小川 彰：地域医療における大学病院の役割. 医のあゆみ (2009) $228,254-258$.

3 ）松本正俊, 井上和夫, 竹内啓祐：エビデンスに基づく地域医療教 育一文献レビューと政策への適用一。医療と社会（2012）22, 103-112.

4 ) 吉田カネ子, 熊倉俊一：島根県自治体に抢ける医療問題と医療施 策の実態.島根大医紀 (2011) 34，49-58.

5 ) 吉岡みち子, 熊倉俊一：地域医療を守る住民活動のあり方の検 討. 島根大医紀（2011） 34，43-48.

6 ）中村伸一, 三瀬順一, 梶井英治, 松本正俊, 中村好一, 定金敦 子，青山泰子，渡辺暁紀，古屋 聡，中田祐広，米澤文雄，高橋 昭彦，他：地域医療テキス卜，自治医科大学監修，医学書院，東 京（2011） pp 23-33. 